\title{
Locally Advanced Pancreatic Neuroendocrine Carcinoma
}

National Cancer Institute

\section{Source}

National Cancer Institute. Locally Advanced Pancreatic Neuroendocrine Carcinoma. NCI Thesaurus. Code C155933.

A pancreatic neuroendocrine carcinoma that has spread from its original site of growth to nearby tissues or lymph nodes. 